\title{
Impact of Situational and Dispositional Factors on Work- Family Conflict and Job Satisfaction: A Proposed Framework
}

\author{
Rohani Salleh ${ }^{1, *}$, Zurina Abu Bakar ${ }^{2}$, and Mumtaz Ali Memon ${ }^{3}$ \\ ${ }^{1,2}$ Department of Management and Humanities, Universiti Teknologi PETRONAS, 32610 Seri Iskandar, Malaysia \\ ${ }^{3}$ School of Management, Air University, 44000 Islamabad, Pakistan
}

\begin{abstract}
Job satisfaction has become an empirical attention as subject of inquiry in many fields. Past studies have revealed that employees with higher level of job satisfaction mostly enjoyed their job, had higher productivity and eventually contributed to generate profit for their organization. Despite its popularity, there is still lacking in determining what exactly drives employee satisfaction from the perspective of situational and dispositional factors. Moreover, the role of mediator in is also rather limited. The present paper proposes a conceptual model from the perspective of situational factors (role overload and role conflict) and dispositional factor (core self-evaluations) to understand the concept of job satisfaction. Specifically, it is suggested that when an employee experiences either role overload, role conflict or perceive with negative core self-evaluation, one of the consequence was increased level of work-family conflict. Ultimately, individuals who perceive higher level work-family conflict will experience less job satisfaction. Recommendations for future research are also discussed.
\end{abstract}

Keywords- role overload, role conflict, core self-evaluations, work-family conflict, job satisfaction

\section{Introduction}

Through past decades, job satisfaction has always become an empirical attention as subject of inquiry in many fields such as industrial/organization psychology, organizational behavior, and social psychology (Judge et al., 2017). Specifically, job satisfaction refers to a situation whereby employee perceive their favorable or unfavorable feelings and excitements towards their work (Newstrom, J.W., \& Davis, K., 2002). Apparently, job satisfaction is reported to be associated with many important organizational outcomes. For example, many scholars demonstrated that organizations which give satisfaction to their employees were more likely seen to achieve high performance (Moradi, Almutairi, Idrus, \& Emami, 2011; Robbins, 2003). In addition, it was found that lack of job satisfaction was a major predictor to reduce organizational commitment (Faridi, A., Baloch, A., \& Wajidi, A., 2017), increase the level of absenteeism (Ibrar M, 2015) and increase turnover intention (Shaw, 1999). In brief, given these negative consequences, henceforth this paper emphasizes that it is important to focus on the predictors that affect the level of job satisfaction.

Several studies have confirmed that situational factors which consists of role conflict and role overload often view as key predictors to the occurrence work-family conflict, consequently give impact on lack job satisfaction. For instance, evidence from Nasurdin \& O'Driscoll (2012) and Illies et al., (2015) study confirmed that role overload significantly related with work-family conflict. Similarly, Abd Razak et al. (2011) in their study also found role overload can caused to higher level of work-family conflict. In supporting this finding, a study by Ahmad (2010) which examined the effect of role overload and work-family conflict among junior physicians in Malaysia revealed a high correlation between these two constructs.

In such, much of the empirical research has documented role conflict associated positively with work-family conflict (Erdamer \& Demirel, 2014; Kim and Ling, 2001; Carlson, Kacmar, \&Williams, 2000), in varies work setting. Specifically,

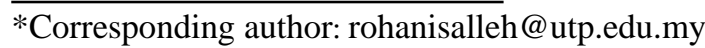


explorative research studying in Malaysia by MJYC, EE et al., (2017) was reported that role conflict had significant relationship with work-family conflict despite of different gender and age. To date, research has tended to focus on role overload, role conflict and work-family conflict. However, there has been little discussion about how work-family conflict mediate the relationship between role overload, role conflict and job satisfaction.

Next, it is proposed that core self-evaluations as dispositional factor in determining the level of work-family conflict. Fundamentally, the basic idea of core self-evaluations was introduced by Judge et. al., (1997) which mainly highlighted a higher-order individual differences construct contained of four broad traits representing a global self-evaluation about oneself and self-worth (Judge, Locke, \& Durham, 1997; Judge, Locke, Durham, \& Kluger, 1998). While Judge and colleagues have found that core self-evaluations have a positive relationship with employee job satisfaction, performance, and life satisfaction (Judge \& Bono, 2001; Judge et al., 2005). A study by Boyar \& Mosley (2007), on the other hand, revealed that individuals who perceived with high core self-evaluations could be able to reduce work-family conflict. Nevertheless, Bono \& Judge (2003) in their studied agreed that operational definitions of the dispositions have not been consistent, yet the role core self-evaluations as major predictor of work-family conflict is unclearly justified. Moreover, most conducted studies on the relationships between core self-evaluations, work-family conflict and job satisfaction have been done in the United States, while fewer studies conducted about the link in Asean countries (Yamazaki, 2012). Therefore, this study proposes a predictor for work-family conflict and job satisfaction from the perspective of dispositional factor.

Despite the important roles of situational factors in determining work-family conflict (Devi KR, Rani SS, 2016; Brack \& Allen, 2003), yet there is still scarce study on dispositional factors in understanding how it give impact on work-family conflict (Kroeker, 2008), particularly focusing on core self-evaluations. Basically, work-family conflict is about conflict that occurred when work and family are mutually incompatible in some respect (Greenhaus \& Beutell, 1985). Numerous studies on work-family conflict had associated to such consequences including lower job satisfaction (Beutell, 2010; Karatepe and Kilic, 2007; Karatepe and Sokmen, 2006), family satisfaction and well-being (Kinnunen et al., 2010; Lu et al., 2010). Studies, (e.g., Riley, 2012; Boyar and Mosley, 2007) have shown that work-family conflict mediates the relationship between situational factors (eg role overload and role conflict) and dispositional factor (eg. core self-evaluations) with job satisfaction. Hence, the present study proposes WFC as a potential mediator between proposed predictors and job satisfaction.

The present study aims to conceptualize the role of work-family conflict as mediator in order to enhance proposed conceptual model. Despite limited studies considered work-family conflict as a mediator, yet there is also no published study has conceptualized work-family conflict as a mediator between situational factors (role overload and role conflict) and dispositional factor (core self-evaluations) with job satisfaction. Thus, by proposing a mediating model to better explain the phenomenon, it is hope that this study may contributes in enriching the literature of role overload, role conflict, core selfevaluations and job satisfaction. The next section justifies on the relationship between role overload, role conflict, core selfevaluations and job satisfaction. Towards the end of this paper, the role of work-family conflict as mediator is discussed further.

\section{Literature Review}

\subsection{Job satisfaction}

Arnold and Feldman (1986, p.86) defined job satisfaction as "the amount of overall affect that individuals have toward their job”. Accordingly, Eren (1989) believed that job satisfaction is about the experience of feeling joyful and benefits obtained once individual complete their tasks successfully. Seemingly, Erdoğan (1997) in his study revealed that feeling satisfied at work is essential since it will encourage an individual to develop positive attitudes towards his/her job. In short, job satisfaction is individuals' sensation of enjoyed or love the job they do, in which will optimize their productivity, feeling happy and eventually achieve organizational mission (Erdamar \& Demirel, 2016).

Although the job satisfaction continuously increased its popularity as research topic in organizational behaviour literature, Westover \& Taylor (2010) argued that there is lacking finding in determining what exactly drives employee 
satisfaction. Therefore, to understand the concept of job satisfaction, this paper proposes a conceptual model which content both perspective of situational factors and dispositional factor. For instance, it has been suggested that when an employee experiences either role overload or role conflict, one of the consequences has been a decreased level of job satisfaction. Moreover, the association between core self-evaluations and job satisfaction is significant (Brown, Ferris, Heller, \& Keeping, 2007; Judge, Ilies, \& Zhang, 2012). In such, past studies consistently shown that job satisfaction to be directly or indirectly related to one or both directions of work-family conflict (Adams, King, \& King, 1996; Bacharach et al., al., 1991; Frone, Yardley et al., 1997). In other words, an interesting possibility of the process model suggests that role overload, role conflict and core self-evaluations are important predictors of work-family conflict, which are in turn interrelated to job satisfaction.

\subsection{Role overload and work-family conflict}

Role overload is described as situations whereby employees identify themselves faced with too many responsibilities which expected to be accomplish within a little time available, yet beyond their abilities to performs, and other constraints as well (Rizzo, House, \& Lirtzman, 1970). This understandable definition is most accepted in the literatures. After 20 years, Bacharach et al., (1990) conceptualized role overload as discussed employees' inability to complete consigned tasks effectively due to time limitations (ie., the conflict between time), eventually lead employees using personal time to rectify work demands (Duxbury and Higgins, 2001). Several studies (Colligan \& Higgins, 2005; Newton \& Jimmieson, 2008; Judy, 2010) extremely believed that individual who heavily burden with workload will give impact on their health, attitudes, and behaviors. Other undesirable results of role overload include increase the level of work-family conflict and ultimately lower organization's overall profitability (Riley, 2012; Muasya, 2015).

With regards to role overload, various studies have shown that role overload has been directly linked to work-family conflict. For instance, a study conducted by Frone et al. (1997) reported that role overload was significantly and positively associated with work-family conflict. To support this notion, a study by Ahmad (2010) who investigated female physicians in public hospitals in Peninsular Malaysia was revealed that role overload is one of central predictor for work-family conflict. The strong association between role overload and work-family conflict is consistent with the findings of prior studies (Greenhaus and Beutell, 1985; Lingard and Francis, 2007). Similarly, the findings of Rimi and Rubel (2013) disclosed that role overload has positive relationship with work-family conflict. Therefore, to reduce this negative consequence, there is a need to pay attention on the relationship between role overload and work-family conflict.

\subsection{Role conflict and work-family conflict}

Role conflict has been defined by Rizzo et al., (1970) as "the contradicting roles carried out by an individual in an organization". While Glissmeyer et al., (1985) defined role conflict "the level to which a person experiences pressures within one role that is incompatible with pressures that take place within another role". Specifically, role conflict exists when individuals are required to perform two or more tasks simultaneously which hardly to accomplish or when an individual is expected to perform tasks that are beyond of their professional scope of practice (Jahawar, Stone, \& Kisamore, 2007). The most alarming aspect of role conflict were that it has led to lower organization commitment (Fisher, D. M., 2014), and ultimately job-related burnout (Maslach, Schaufeli, \& Leiter, 2001). On the other hand, role conflict also can lead to lower levels of work-family conflict (Ballout, 2008).

Several studies have tried to examine the relationship between role conflict and work-family conflict (eg Ryan, B., Jintao, M., \& Minyen, K., 2008; Bakar, Z. A., \& Salleh, R., 2015). Specifically, a study conducted by Kim and Ling (2012) revealed that role conflict facing by women entrepreneurs in Singapore are positively correlated to work-family conflict. In supporting the view, a study on time effect of role stress on psychological strain among lecturers in public universities in Malaysia was explored the positive relationship between role conflict and work-family conflict (Idris, 2011). Similarly, Beigi et al., (2012) confirmed that role conflict was positively associated with work-family conflict among Iranian operating room 
personnel. In short, the unresolved role conflict problem is demand for more research conducted to test the effects of role conflict among various populations employed in a variety of work settings (Carolina, 2010).

\subsection{Core self-evaluation and work-family conflict}

Core self-evaluations is defined as "the fundamental assessments that people make about their wellness, competence and capabilities" (Judge et al., 2005, p. 257). Specifically, core self-evaluations is composited with four traits namely as selfesteem, locus of control, self-efficacy, and neuroticism. According to Judge et al., (2003), although the four traits are conceptually similar and have share some unique variance, however there is "considerable redundancy". According to Kammeyer-Mueller et al., (2009), individual with higher level of positive core self-evaluations were always view their job tasks in positive ways and be able to cope with workplace challenges.

Given the links of core self-evaluations with work-family conflict, it mainly been supported in the previous studies (eg. Kroeker, 2008; Haines et al., 2013). Specifically, a book chapter by Friede and Ryan (2004) argues that people with more positive core self-evaluations will experience less work-family conflict. Interestingly, a study conducted by Friede \& Jill (2008) confirmed that core self-evaluations to be negatively correlated with work-family conflict. In general, these findings lend support to the notion that individuals with higher core self-evaluations anticipate less work-family conflict. Consistent with another study, Westring \& Ryan (2011) who investigated on medical students at a large Midwestern university revealed that core self-evaluations is a global evaluation of the self, which strongly related to work-family conflict. Since its introduction, core self-evaluations has become a dominant topic of investigation since it has been associated to a variety of phenomena such as satisfaction (Judge, Locke, Durham, \& Kluger, 1998). Nevertheless, despite its increasing popularity and as the potential limitations associated with the construct, future research on core self-evaluations literature to date seems needed due to an increased concern from educators regarding job satisfaction (Chang, Ferris, Johnson, Rosen, \& Tan, 2012). Accordingly, the present study attempts to examine the core self-evaluations as potential predictors of job satisfaction and the plausible mediating role of work-family conflict.

\subsection{Mediating role of work-family conflict}

Work-family conflict is defined as "a form of interrole conflict in which role pressures from the work and family domains are mutually incompatible in some respect" (Greenhaus \& Beutell, 1985, p. 77). Work-family conflict often viewed as a bidirectional dimension which consist of two components namely work interfering with conflict (conflict occurred when work roles interfere with family roles) and family interfering with work (conflict occurred when family-related roles interfere with work-related roles) (Neerpal and Barath, 2013; Kossek and Ozeki, 1998). Apart of work-family conflict antecedents, empirical literatures emphasized that work related antecedents were more strongly related to work related outcomes; while family related antecedents were more strongly related to family related outcomes of work-family interface (Bicaksiz,2009).

In most of the studies (eg. Cloninger et al., 2015; Crain, T.L et al., 2014; Kinnunen et al., 2010) have examined work-family conflict negatively impacted numerous individual and organizational outcomes. For instance, research has shown that workfamily conflict is related to increased turnover intentions, reduced job satisfaction and family satisfaction ( $\mathrm{Lu}$ et al., 2017; Beutell, 2010; Spector et al., 2007). Further, in study by Neerpal and Barath (2013) which investigated police department in India argued that organizations should embrace possible actions in order to reduce work-family conflict and increased job satisfaction. While a more recent study by Soomro, AA et. al., (2018) confirmed that the negative and significant relationship between work-family conflict and job satisfaction was supported. Several other scholars also found that role conflict, role overload and core self-evaluations influence employees' job satisfaction (Mustapha \& Yu Ghee, 2013; Chang, Ferris, Johnson, Rosen, \& Tan, 2012; Koustelios, Theodorakis \& Goulimaris, 2004).

Work-family conflict has been increasingly seen as a potential mediator (Mauno, Kinnunen, \& Pyykko, 2005), between several situational factors and dispositional factors with job satisfaction. Studies conducted consistently proven that the role conflict, role overload and work-family conflict (eg Riley, 2012; Baral \& Bhargava, 2011; Ballout, 2008) are positively related 
to work-family conflict, which in turn, mediates the relationship between the predictors (role conflict, role overload and core self-evaluations) and job satisfaction (Kroeker, 2008). Supporting to this notion, Riley (2012) found that work-family conflict as a mediator between role overload and job satisfaction. However, Boyar and Mosley (2007) used to argue that there have been no publish study link work-family conflict and work-family conflict by year 2007. Therefore, researcher introduced the mediating role of work-family conflict in the relationship between core self-evaluations and job satisfaction for the first time. In another study, a meta-analysis of 178 studies (Ford, Heinen \& Langkamer, 2007) concluded that workfamily conflict mediates the relationship between work stressors and job satisfaction. Seemingly, Cabrera (2013) further confirmed the job demands are connected to work-family conflict as mediator which in turn, significantly related to job satisfaction.

Conversation resources theory (COR) was discussed as employees' competency to achieve, sustain and how they secure things they worth, which is resources. When individuals fail to replenish the lost resources (Ngah, Ahmad, Hamid \& Ismail, 2010), then the psychological strain is expected to occur. Specifically, the COR theory is a vital step forward in theorizing on work-family conflict because it clarifies why people act when confronted with a conflict and not just when they experience strain. Moreover, COR theory is very much relevant to this research model in a sense that, role overload and role conflict threatens an individual's resources, and over time, lengthy experience with multiple roles in hand would result in strain, such as work-family conflict (Tsai,2008). Thus, the potential or actual loss of these resources results in low job satisfaction.

\section{PROPOSED CONCEPTUAL FRAMEWORK}

This paper attempts to conceptualize the mediating effect of work-family conflict between the role overload, role conflict, core self-evaluations and job satisfaction. In addition, COR was adopted to develop theoretical linkages among the constructs. It is postulated that work-family conflict will mediate the relationship between role overload, role conflict, core self-evaluations and job satisfaction. Specifically, individuals with a higher level of work-family conflict would be likely to have a low job satisfaction. Figure 1 shows the conceptual framework of the study.

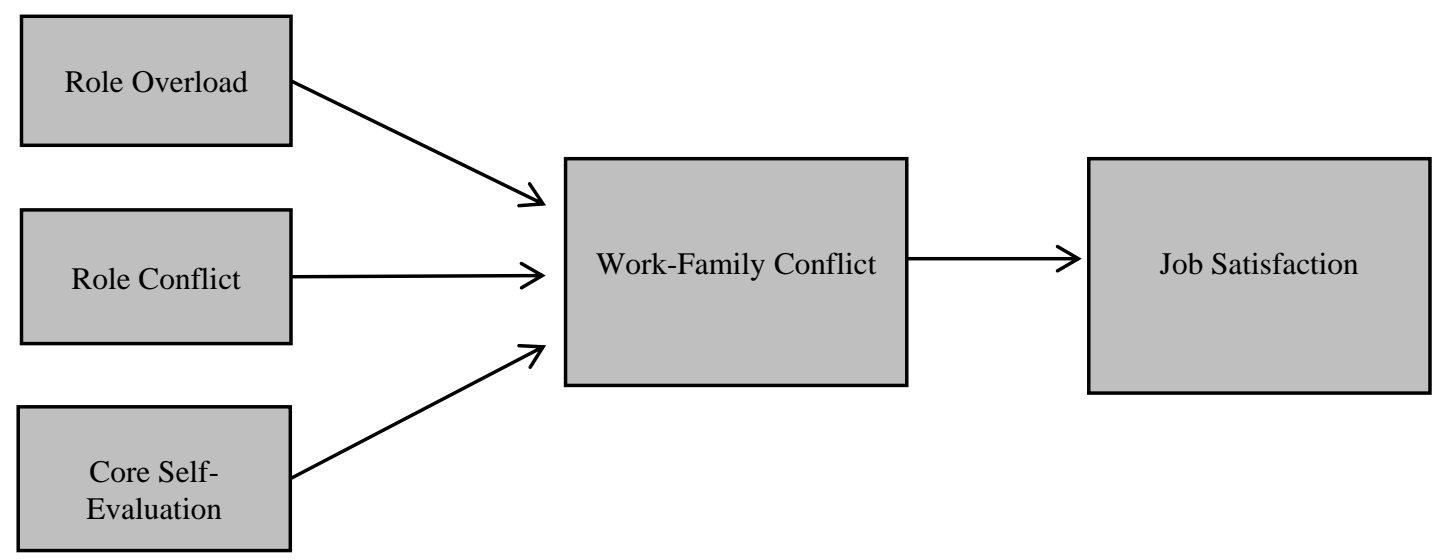

Figure 1: The conceptual framework

\section{CONCLUSION}

Role overload, role conflict and core self-evaluations play an essential part as predictors to determine the level of workfamily conflict. While the issue of lower job satisfaction becomes a severe threaten to organization, enhancing employee work-family conflict can be crucial element in order to sustain the productivity. Ultimately, past studies have indicated that individual who confront with high level of work-family conflict are generally unsatisfied with their jobs. This paper assimilates work-family conflict as a mediator between role overload, role conflict, core self-evaluations and job satisfaction, 
as a response to the recent calls of research. Thus, future research could also investigate work-family conflict as great potential between other proposed predictors and job satisfaction to validate and extend the proposed model.

\section{REFERENCES}

Abd Razak, A. Z. A., Mohd Nasurdin, A., \& Yeop Yunus, N. K. (2011). The impact of work overload and job involvement on work-family conflict among Malaysian doctors. Labuan E-Journal of Muamalat and Society, 5, 1-10

Adams, G.A., King, L.A. and King, D.W. (1996). Relationships of job and family involvement, family social support, and work-family conflict with job and life satisfaction. Journal of Applied Psychology, 81(4), 411-420.

Ahmad, S., \& Skitmore, M. (2003). Work-family conflict: A survey of Singaporean workers. Singapore Institute of Management, 25(December 2001), 35-52.

Ahmad, A. (2010). Work-family conflict among junior physicians: Its mediating role in the relationship between role overload and emotional exhaustion. Journal of Social Sciences, 6(2), 265-271.

Arnold, J. \& Feldman, C. (1986). Organizational behavior. New York: McGraw Hill Book.

Bacharach, S.B., Bamberger, P. and Conley, S. (1991). Work-home conflict among nurses and engineers: Mediating the impact of role stress on burnout and satisfaction at work. Journal of Organizational Behaviour, 12(1), 39-53.

Bakar, Z. A., \& Salleh, R. (2015). Role demands, work-family conflict and motivation: A proposed framework. Global Business and Management Research: An International Journal, 7, 78.

Baral, R., \& Bhargava, S. (2011). Predictors of work-family enrichment: moderating effect of core self-evaluations. Journal of Indian Business Research, 3(4), 220-243.

Ballout, H. I. (2008). Work-family conflict and career success: the effects of domain-specific determinants. Journal of Management Development, 27(5), 437-466.

Beigi, M., Ershadi, S. M., \& Shirmohammadi, M. (2012). Work-family conflict and its antecedents among Iranian operating room personnel. Management Research Review, 35(10), 958-973.

Beutell, N. J. (2010). Work schedule, work schedule control and satisfaction in relation to work-family conflict, work-family synergy, and domain satisfaction. Career Development International, 15(5), 501-518.

Bicaksiz, P. (2009). The effects of gender role ideology, role salience, role demands and core self-evaluations on work-family interface. Master of Science, Middle East Technical University, (September), 144.

Bondy, J. (2012). Job Satisfaction, Role Overload and Gender. Journal of Veysel Bozkurt, 1(1), 51-67.

Bono, J. E., \& Judge, T. A. (2003). Core self-evaluations: A review of the trait and its role in job satisfaction and job performance. European Journal of Personality, 17, 5-18.

Boyar, S.L. and Mosley, D.C. (2007). The relationship between core self-evaluations and work and family satisfaction: The mediating role of workfamily conflict and facilitation. Journal of Vocational Behavior, 71(2), 65-281.

Brack, C. S., \& Allen, T. D. (2003). The relationship between big five personality traits, negative, affectivity, type A behavior, and work-family conflict. Journal of Voctaional Behavior, 63, 457-412.

Cabrera, E. F. (2013). Using the job demands-resources model to study work-family conflict in women. International Journal of Management and Business, 4(1), 112-130.

Carolina, D. S. (2010). Correlates of job-related burnout in nurse managers working in hospitals. Doctor of Philosophy, The State University of New Jersey.

Chang, C.-H., Ferris, D. L., Johnson, R. E., Rosen, C. C., \& Tan, J. A. (2012). Core self-evaluations: A review and evaluation of the literature. Journal of Management, 38(1), 81-128.

Chen, Y. S., Chen, M. C., Chou, F. H. C., Sun, F. C., Chen, P. C., Tsai, K. Y., \& Chao, S. S. (2007). The relationship between quality of life and posttraumatic stress disorder or major depression for firefighters in Kaohsiung, Taiwan. Quality of Life Research, 16, $1289-1297$.

Cloninger, P. A., Selvarajan, T. T., Singh, B., \& Huang, S. (Charlie). (2015). The mediating influence of work-family conflict and the moderating influence of gender on employee outcomes. The International Journal of Human Resource Management, 26, $2269-2287$.

Colligan, T.W. and Higgins, E.M. (2005). Workplace stress: etiology and consequences. Journal of Workplace Behavioral Health, 21, 89-97.

Crain, T.L., Hammer, L.B., Bodner, T., Kossek, E.E., Moen, P., Lilienthal, R., \& Buxton, O.M. (2014). Work-family conflict, family-supportive supervisor behaviors (FSSB), and sleep outcomes. Journal of Occupational Health Psychology, 19, 155-167.

Devi KR, Rani SS (2016). The impact of organizational role stress and work-family conflict: diagnosis sources of difficulty at work place and job satisfaction among women in IT sector, Chennai, Tamil Nadu. Procedia-Social and Behavioral Sciences, 219, 214-220

Duxbury, L., \& Higgins, C. (2001). Work-life balance in the new millennium: Where are we? Where do we need to go?. Canadian Policy Research Networks discussion paper No.W/12, Ottawa, ON

Erdamar, G., \& Demirel, H. (2014). Investigation of work-family, family-work conflict of the teachers. Procedia - Social and Behavioral Sciences, $116,4919-4924$.

Erdamar, G., \& Demirel, H. (2016). Job and life satisfaction of teachers and the conflicts they experience at work and at home. Journal of Education and Training Studies, 4(6), 164-175.

Eren, E. (1989). Yönetim psikolojisi. [Management psychology] Genişletilmiş 3. Baskı, İstanbul: Yön Ajans.

Faridi, A., Baloch, A., \& Wajidi, A. (2017). Job satisfaction and organizational commitment under Traditional and modern T\&D program: Evidence from public banking sector of Pakistan, International. Journal of Applied Business and Management Studies, 2(1), 9-16.

Feng Cao. (2005). Exploring the relations among availability of temporal flexibility at work, work-to-family conflict and job satisfaction. Doctor of Philosophy Degree Department, Southern Illinois University Carbondale.

Fisher, D. M. (2014). A multilevel cross-cultural examination of role overload and organizational commitment: Investigating the interactive effects of context. Journal of Applied Psychology, 99, 723-736.

Frone, M. R., Yardley, J. K., \& Markel, K. S. (1997). Developing and testing an integrative model of the work-family interface. Journal of Vocational Behavior, 50, 145-167. 
Ford,M. T.,Heinen, B. A. \& Langkamer, K. L. (2007),Work and family satisfaction and conflict: A meta-analysis of cross-domain relations. Journal of Applied Psychology, 92, 57-80.

Glissmeyer, M., James W. Bishop \& R. Fass, D. (1985), Role conflict, role ambiguity, and intention to quit the organization: The case of law enforcement Officers. Journal of Academic Management, 40(1), 82-111.

Greenhaus, J.H. \& Beutell, N.J. (1985). Sources of conflict between work and family roles. Academy of Management Review, 10, 76-88.

Haines, V.Y., Harvey, S., Durand, P., Marchand, A., 2013. Core self-evaluations, work-family conflict, and burnout. Journal of Marriage Family, 75, 778-793.

Hang-yue, N., Foley, S., \& Loi, R. (2005). Work role stressors and turnover intentions: A study of professional clergy in Hong Kong. The International Journal of Human Resource Management, 16(11), 2133-2146.

Ibrar M (2015). The influences of employee job satisfaction an organizational commitment on turnover intention. Journal of Business Management Review, 6(1).

Idris, M. K. (2011). Over time effects of role stress on psychological strain among Malaysian public university academics. International Journal of Business and Social Science, 2(9), 154-161.

Ilies, R., Ryan, A. M., Huth, M., \& Dimotakis, N. (2015). Explaining the links between workload, distress, and work-family conflict among school employees: physical, cognitive, and emotional fatigue. Journal of Educational Psychology, 12.

Jawahar, I.M., Stone, T.H., \& Kisamore, J.L. (2007). Role conflict and burnout: The direct and moderating effects of political skill and perceived organizational support on burnout dimensions. International Journal of Stress Management, 14(2), 142-159.

Judge, T. A., Locke, E. A. \& Durham, C. C. (1997). The dispositional causes of job satisfaction: A core evaluations approach. Research in Organizational Behavior, 19, 151-188.

Judge, T. A., Locke, E., Durham, C., \& Kluger, A. (1998). Dispositional effects on job satisfactions and life satisfaction: The role of core evaluations. Journal of Applied Psychology, 83, 17-34.

Judge, T. A., Erez, A., Bono, J. E., \& Thoresen, C. J. (2003). The core self-evaluations scale (CSES): Development of a measure. Personnel Psychology, 56, 303-331.

Judge, T. A., Piccolo, R. R., \& Ilies, R. 2004. The forgotten ones? The validity of consideration and initiating structure in leadership research. Journal of Applied Psychology, 89(1), 36-51.

Judge, T. A., Bono, J. E., Erez, A., \& Locke, E. A. (2005). Core self-evaluations and job and life satisfaction: The role of self-concordance and goal attainment. Journal of Applied Psychology, 90(2), 257-268.

Judge, T. A., Ilies, R., \& Zhang, Z. (2012). Genetic influences on core self-evaluations, job satisfaction, and work stress: A behavioral genetics mediated model. Organizational Behavior and Human Decision Processes, 117(1), 208-220.

Judge, T. A., Weiss, H. M., Kammeyer-Mueller, J. D., \& Hulin, C. L. (2017). Job attitudes, job satisfaction, and job affect: A century of continuity and of change. Journal of Applied Psychology, 102, 356-374.

Judy, M. R. (2010). Relationship of role overload to job satisfaction and intent to leave among acute care nurses. Doctor of Education, Universiity of Phoenix.

Kammeyer-Mueller, J. D., Judge, T. a, \& Scott, B. a. (2009). The role of core self-evaluations in the coping process. The Journal of Applied Psychology, 94(1), 177-195.

Karatepe, O.M. and Baddar, L. (2006). An empirical study of the selected consequences of frontline employees' work-family conflict and familywork conflict. Tourism Management, 27(5), 1017-1028.

Karatepe, O.M. and Kilic, H. (2007). Relationships of supervisor support and conflicts in the work-family interface with the selected job outcomes of frontline employees. Tourism Management, 28(1), 238-252.

Kim, J. and Ling, C. (2001). Work-family conflict of women entrepreneurs in Singapore. Women in Management Review, 16(5), $204-221$.

Kinnunen, U., Feldt, T., Mauno, S., \& Rantanen, J. (2010). Interface between work and family: A longitudinal individual and crossover perspective. Journal of Occupational and Organizational Psychology, 83(1), 119-137.

Kossek, E. E. \& Ozeki, C. (1998), Work-family conflict, policies and the job-life satisfaction relationship: A review and directions for organizational behavior- human resources research. Journal of Applied Psychology, 82, 359-375.

Kroeker, J. M. (2008). The relationship between core self-evaluation traits and work family conflict. Master of Science, Emporia State University.

Lu, L., Cooper, C., Kao, S.F., Chang, T.T., Allen, T.D., Lapierre, L.M., O’Driscoll, M.P., Poelmans, S.A.Y., Sanchez, J. and Spector, P.E. (2010). Cross-cultural differences in work-to-family conflict and role satisfaction: A Taiwanese-British comparison. Human Resource Management, 49(1), 67-85

Lu, Y., Hu, X. M., Huang, X. L., Zhuang, X. D., Guo, P., Feng, L. F., \& Hao, Y. T. (2017). The relationship between job satisfaction, work stress, work- family conflict, and turnover intention among physicians in Guangdong, China: A cross-sectional study. BMJ Open, 7(5), 1-13

Mauno, S., Kinnunen, U., \& Pyykko, M. (2005). Does work-family conflict mediate the relationship between work-family culture and self-reported distress? Evidence from five Finnish organizations. Journal of Occupational and Organizational Psychology, 78(4), 509-530.

MJYC Ee, WMY Teoh and YY Yen (2017). Role conflict, role ambiguity and role overload: The strains of work-family conflict. Journal of Social Sciences, 12 (9), 1566-1576.

Moradi, E., Almutairi, D. O., Idrus, D., \& Emami, R. (2011). The influence of organizational learning culture on job satisfaction among academic staff. Journal of Global Management, 1-12

Morgan, L. (2009). The impact of marketing employee satisfaction on service quality. Doctor Of Business Administration, Nova Southeastern University.

Muasya, G. (2015). The relationship between stressors, work-family conflict and burnout among female teachers in Kenyan urban schools. Doctor of Philosophy, Arizona State University.

Nasurdin, A. M., \& O'Driscoll, M. P. (2012). Work overload, parental demand, perceived organizational support, family support, and work-family conflict among New Zealand and Malaysian academics. New Zealand Journal of Psychology, 41(1), $38-48$.

Newton, C. J., and Jimmieson, N. L. (2008). Role stressors, participative control, and subjective fit with organisational values: Main and moderating effects on employee outcomes. Journal of Management \& Organization 14(1), 20-39.

New John W. and David Keith (2002). Organizational Behaviour, Tata Mcgraw Hill Pub. Co. Ltd.

Ngah, N., Ahmad, A., Hamid, T. A. T. A., \& Ismail, A. (2010). The Mediating Role ofWork-family Conflict in the Relationship between Supervisor Support and Job Satisfaction. The International Journal of Interdisciplinary Social Sciences, 4(11), 197.

Pearson, Q.M. (2008). Role overload, job satisfaction, leisure satisfaction, and psychological health among employed women. Journal of Counselling \& Development, 86, 57-63.

Pinsker, S. (2012). Job satisfaction among social workers: Satisfaction with facets of the job and overall satisfaction, and the impact of work-family 
conflict and disposition. Doctor of Philosophy, New York University School of Social Work.

Pleck, J.H., Staines, G.L. and Lang, L. (1980). Conflicts between work and family life. Monthly Labor Review, 103(3), 29-32.

Rathi, N., \& Barath, M. (2013). Work-family conflict and job and family satisfaction: Moderating effect of social support among police personnel. Equality, Diversity and Inclusion: An International Journal, 32(4).

Riley, D. (2012). Work and family interface: Wellbeing and the role of resilience and work-life balance. Doctor of Philosophy, University of Waikato.

Rizzo, J. R., House, R. J., \& Lirtzman, S. I. (1970). Role conflict and ambiguity in complex organizations. Administrative Science Quarterly, 15(2), 150-163.

Robbins, S. P. (2003). Organizational behavior. Upper Saddle River, NJ: Prentice Hall.

Shaw, J. D. (1999). Job satisfaction and turnover intentions: The moderating role of positive affect. Journal of Social Psychology, 139, $242-244$.

Ryan, B., Jintao, M., \& Minyen, K. (2008). Role conflict, role ambiguity and work-family conflict among university foodservice managers. International CHRIE Conference-Refereed Track.17.

Spector, P.E., Allen, T.D., Poelmans, S.A.Y., Lapierre, M.L., Cooper, C.L. and Widerszal-Bazyl, M. (2007). Cross-national differences in relationships of work demands, job satisfaction, and turnover intentions with WFC. Personnel Psychology, 60(4), 805-835.

Tsai, H.-Y. (2008). Work-family conflict, positive spillover, and emotions among Asian American working mothers. Doctor of Philosophy (Psychology), The University of Michigan.

Westover, J. H., \& Taylor, J. (2010). International differences in job satisfaction: The effects of public service motivation, rewards and work relations. International Journal of Productivity and Performance Management, 59(8), 811-828.

Westring, A. F., \& Ryan, A. M. (2011). Anticipated work-family conflict: A construct investigation. Journal of Vocational Behavior, $79(2), 596610$.

Yamazaki, Y. (2012). Job satisfaction and confidence of Asian managers in Japanese MNCs. Journal of Economics \& Management Series, 12(1). 